\title{
Socio-Economic Conditions of the Fringe Villagers of Kaziranga National Park (KNP), Assam, India
}

\author{
Biju Borah $^{1 *}$, Atul Borgohain ${ }^{1}$, L.S. Khuman ${ }^{2}$, Gautam Bordoloi ${ }^{2}$, Raju Dewri ${ }^{1}$, \\ Mrinal Kalita ${ }^{1}$ and Kongkon J. Dutta ${ }^{1}$ \\ ${ }^{1}$ College of Veterinary Science, A.A.U., khanapara, Guwahati, Assam-781022, India \\ ${ }^{2}$ Lakhimpur College of Veterinary Science, A.A.U, Joyhing, North Lakhimpur, \\ Assam-787051, India \\ *Corresponding author
}

A B S T R A C T

\begin{tabular}{|c|}
\hline Keywords \\
\hline $\begin{array}{l}\text { Assam, Condition, } \\
\text { Fringe, Kaziranga } \\
\text { national park, Socio- } \\
\text { economic and Villager }\end{array}$ \\
\hline Article Info \\
\hline $\begin{array}{l}\text { Accepted: } \\
18 \text { April } 2018 \\
\text { Available Online: } \\
10 \text { May } 2018\end{array}$ \\
\hline
\end{tabular}

The survey was undertaken to study the socio-economic conditions of the fringe villagers of KNP region in Assam. A total of 100 respondents were selected from different fringe villages of KNP areas on random basis. From the survey it was found that, about 58 per cent of the fringe respondents were of middle age group (31-47 years) and belonged to schedule tribe (32 per cent) caste. Majority (67 per cent) of the respondents was with nuclear family type and had a medium family size (5 numbers). The educational level was found to be average upto primary school level of education. To sustain their livelihood, agriculture and animal husbandry was found to be their primary occupation in those areas. They had a small land holding (Up to 5 bighas) and usually maintained a medium herd size (3.08-5.24 cattle unit). Amusingly, only 8 percent of the total respondents were found to be involved in social participation. About 51 per cent of them had a medium level of agricultural and animal husbandry experienced and had a low level of mass media exposure (48 per cent). Further, they had a medium level of annual gross income from all sources and from livestock sector respectively.

\section{Introduction}

Kaziranga National Park (KNP) is a world heritage site, famous for the great one horned rhinos and for its rich natural resources. The park is located between latitude $26^{\circ} 30 \mathrm{~N}$ to $26^{\circ} 45 \mathrm{~N}$ and longitude $93^{\circ} 08 \mathrm{E}$ to $93^{\circ} 36 \mathrm{E}$ within two districts in the Indian state of Assam (Nagaon and Golaghat district). There are about 3000 forest fringe villages with a population of approximately 2, 34,113 numbers which are almost surrounding most of the protected area of the state including KNP. Some of the villages are still existed since the existence of the protected area. These settlements are agrarian in nature and livestock rearing is an integral part of their livelihood. In this region, people are poor, their livestock are hardy but yields are poor, though the region is endowed with rich natural resources. The region is not industrially advanced either, being the sole means of the people's livelihood as about $90 \%$ of them dependent on crop farming and animal 
husbandry practices (Baruah, 2000 and Kutum, 2011). Many research studies revealed that work in Kaziranga were mostly restricted to general sociology, archaeological, geographical, ecological and veterinary clinical aspects. None of them accounted the socio-economic life of the fringe villagers in a holistic manner (Borah et al., 2018). Assuming that livelihood status of the fringe villagers to be studied in a holistic way, the present study was conducted to understand and to document their livelihood related social economic realities.

\section{Materials and Methods}

Five (5) fringe villages namely Agoratoli-I, Agoratoli-II, Kohora, Bagori and Burapahar from 4 wildlife ranges of Kaziranga National park were selected for the study. Subsequently, from each of the 5 villages, 20 numbers of fringe villagers were randomly selected making the sample size of 100 . For our generalization, we assumed that all the surrounding fringe villages of Kaziranga was representing by these five fringe villages. Reliability of the interview schedule was worked out by conducting a pre-testing in the fringe villages of Pobitora Wildlife Sanctuary by using 'Test-retest' method and the value was found out to be $r=0.89$. Data were personally collected by the authors. Further, the content validity was done while preparing the final interview schedule. Lastly, the data obtained by the investigation were arranged and statistically analyzed by using SAS9.3 software. The village wise distributions of the respondents are given in Figure 1 and 2.

\section{Results and Discussion}

\section{Socio-personal profile}

A perusal of the data presented in Table 1 indicated that, about 58 per cent of the total respondents in KNP fringe villages fell in the middle aged group. Their average family size was 6 family members per household. These might be due to the fact that all of them were KNP fringe area dependent and virtually shared similar situational antecedents (Hazarika and Anand, 2001). A large majority (67 per cent) of them belonged to nuclear family type and only 33 per cent were belonged to joint family type. So, it could be concluded that the advantages of joint family system was not being aware and this system was slowly declining in due course of time even in rural forest fringe areas (Das, 2005). Concerning caste, the Schedule tribe (32 per cent), OBC (31 per cent), General (22 per cent) and Schedule caste (15 per cent) constituted the pattern of universe in the present study. Similar trend was also observed by Prajapati et al., (2016).

Regarding educational qualification, they mostly had primary level to HSLC level of educational qualification. The findings are in Consonance with the results of Verma et al., $\left(2014^{\mathrm{a}}\right)$ and Borah et al., (2018). About 55 per cent of the respondents had medium duration of dwelling and the rest 30 per cent and 15 per cent had short and long duration of dwelling respectively. This might be attributed to the fact that some fringe villagers were dwelling there since long time whereas, others migrated in the later period. This might also led to a variation in their awareness towards education in those areas (Das, 2005). Amusingly, only 8 percent of the total respondents were found to be involved in social participation which reflected a very low level of social participation among the respondents of Kaziranga fringe villages. Similar pattern of social participation was also reported by Kutum (2011) and Borah et al., (2018). It was also found that majority (51 per cent) of them had medium level of agricultural and animal husbandry experience. The findings are in consonance with the result of Borah et al., (2018) and Verma et al., (2014 ${ }^{\mathrm{b}}$. 
Fig.1 The Study Areas

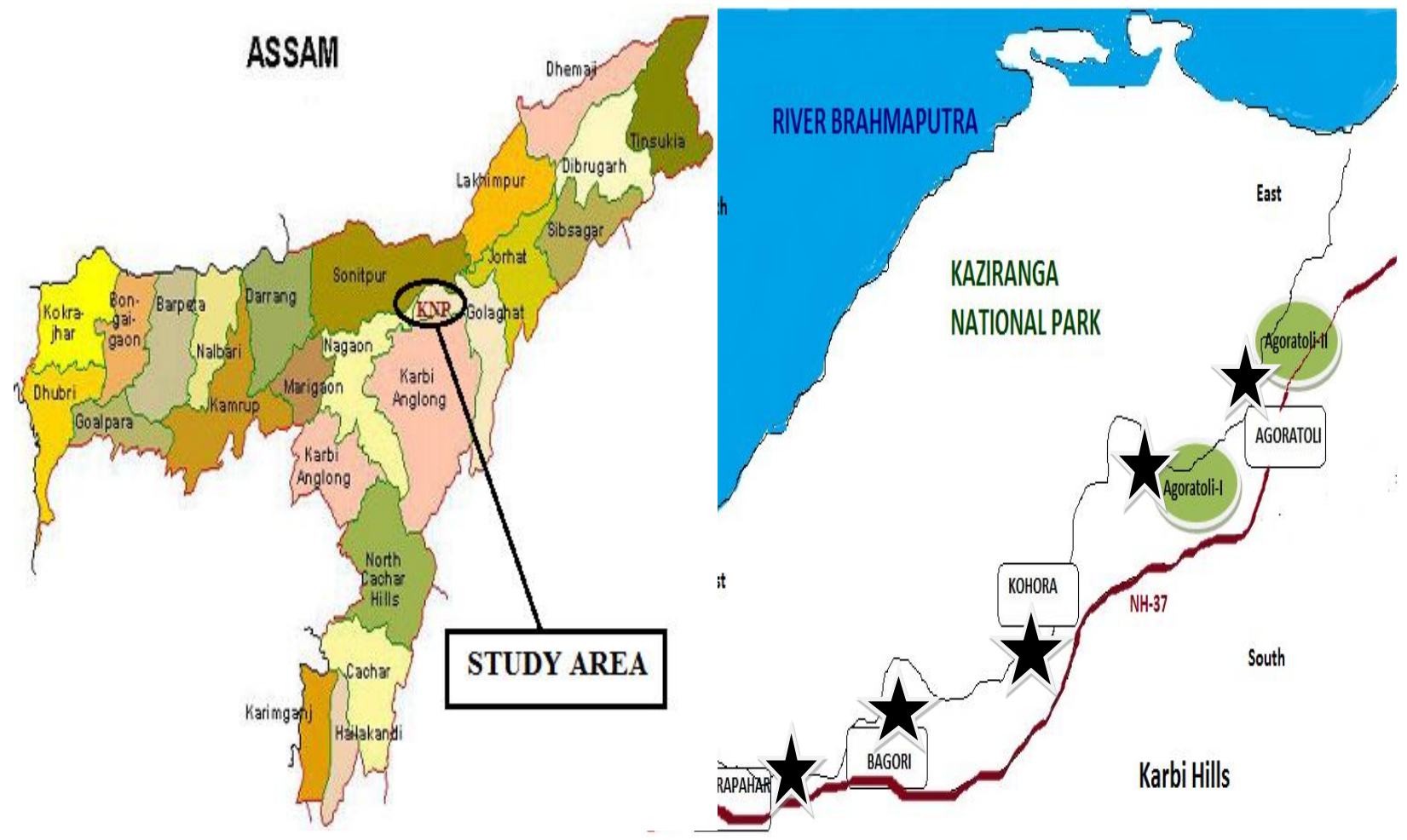

Fig.2 Model of constituting sample size

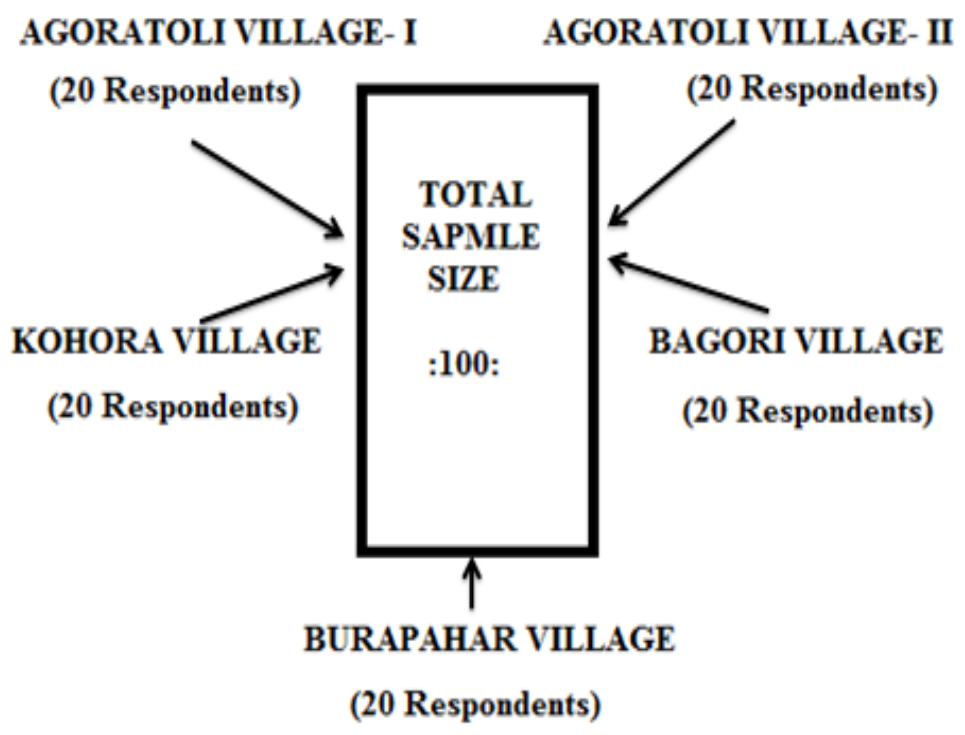




\begin{tabular}{|c|c|c|c|}
\hline \multicolumn{4}{|c|}{ Table.1 Socio- personal characteristics } \\
\hline Sl. No. & characteristics & Categories & Frequency \\
\hline \multirow[t]{3}{*}{1.} & \multirow[t]{3}{*}{ Age } & Young ( $30 \geq$ years $)$ & $22(22)$ \\
\hline & & Middle (31-47 years) & $58(58)$ \\
\hline & & Older ( $48 \leq$ years $)$ & $20(20)$ \\
\hline \multirow[t]{3}{*}{2.} & \multirow[t]{3}{*}{ Family Size } & Small $[4 \geq]$ & $32(32)$ \\
\hline & & Midium [5] & $42(42)$ \\
\hline & & Large $[6 \leq]$ & $26(26)$ \\
\hline \multirow[t]{2}{*}{3.} & \multirow[t]{2}{*}{ Family Type } & Joint & $33(33)$ \\
\hline & & Nuclear & $67(67)$ \\
\hline \multirow[t]{4}{*}{$\overline{4 .}$} & \multirow[t]{4}{*}{ Caste } & General & $22(22)$ \\
\hline & & OBC & $31(31)$ \\
\hline & & ST & $32(32)$ \\
\hline & & $\mathrm{SC}$ & $15(15)$ \\
\hline \multirow[t]{6}{*}{5.} & \multirow[t]{6}{*}{ Educational Status } & Illiterate & $6(6)$ \\
\hline & & PS & $29(29)$ \\
\hline & & MS & $28(28)$ \\
\hline & & HSLC & $25(25)$ \\
\hline & & HSSLC & $11(11)$ \\
\hline & & Graduate & $1(1)$ \\
\hline \multirow{3}{*}{6.} & \multirow[t]{3}{*}{ Years of dwelling } & Short dweller ( 25 years $\geq)$ & $30(30)$ \\
\hline & & Medium (26-68 years) & $55(55)$ \\
\hline & & Long dweller (69 year $\leq$ ) & $15(15)$ \\
\hline \multirow[t]{2}{*}{7.} & \multirow[t]{2}{*}{ Social Participation } & Yes & $8(8)$ \\
\hline & & No & $92(92)$ \\
\hline \multirow[t]{3}{*}{8.} & \multirow[t]{3}{*}{ Experience in agriculture and A.H } & Low $(>15)$ & $32(32)$ \\
\hline & & Medium (15-20) & $51(51)$ \\
\hline & & High $(20<)$ & $17(17)$ \\
\hline \multirow[t]{3}{*}{9} & \multirow[t]{3}{*}{ Mass Media Exposure } & Low $(>3.78)$ & $48(48)$ \\
\hline & & Medium (3.78- 6.90) & $40(40)$ \\
\hline & & High $(6.90<)$ & $12(12)$ \\
\hline \multicolumn{4}{|c|}{ Table.2 Socio- Economic characteristics } \\
\hline Sl. No. & characteristics & Categories & Frequency \\
\hline \multirow[t]{5}{*}{1.} & \multirow[t]{5}{*}{ Primary occupation } & Service & $4(4)$ \\
\hline & & Business/trade and commerce & $1(1)$ \\
\hline & & Agriculture and animal husbandry & $66(66)$ \\
\hline & & Daily wager & $27(27)$ \\
\hline & & Others & $2(2)$ \\
\hline 2. & Herd Size & Small $(3.07 \mathrm{CU} \geq)$ & $6(6)$ \\
\hline & & Medium (3.08-5.24 CU) & $77(77)$ \\
\hline & & Large $(5.25 \mathrm{CU} \leq)$ & $17(17)$ \\
\hline 3. & Land Holding & Up to 5 bighas & $68(68)$ \\
\hline & & 5.1-10 bighas & $29(29)$ \\
\hline & & 10.1 Bighas\& above & $3(3)$ \\
\hline 4. & Annual income & Small (Rs1124 $\geq)$ & $4(4)$ \\
\hline & agriculture and A.H. & Medium (Rs1125-8569) & $78(78)$ \\
\hline & & Large $(\operatorname{Rs} 8570 \leq)$ & $18(18)$ \\
\hline 5. & Annual family Gross income & Small (Rs $38238 \geq$ ) & $0(0)$ \\
\hline & & Medium (Rs38239- Rs 70001) & $89(89)$ \\
\hline & & Large (Rs 70002 $\leq$ ] & $11(11)$ \\
\hline
\end{tabular}


Table.3 Pearson's Correlation analysis between independent and dependent variables

Independent Variable

1. Age

2. Educational Qualification

3. Family size

4. Years of dwelling

5. Land holding

6. Herd size

7. Experience in agriculture and A.H.

8. Mass media exposure

9. Annual income from agriculture \& A.H.

10. Annual family Gross income

Note:

$\mathrm{X}^{1}$-Dependent on forest territory For Livestock rearing rearing

$\mathrm{X}^{2}$ - Assistance for being in fringe area than other area

$\mathrm{X}^{3}$-Degree of assistance for livestock rearing in the fringe area

$\mathrm{X}^{4}$-Veterinary Support

*, Significant at 0.05 level of probability

**, Significant at 0.01 level of probability

Further, it was depicted from Table 1 that, about 48 per cent had low level of mass media exposure followed by medium (40 per cent) and high (12 per cent). The geographical location, water based conveyance with muddy roads, flood etc. seemed as the main reason behind the process of delayed development in those areas, which might also led to lower mass media exposure for the respondents. Similar findings were also reported by Paincra (2010) and Verma et al., $\left(2014^{\mathrm{a}}\right)$ in their respective studies.

\section{Socio-economic profile}

It could be observed from Table 2 that, majority (66 per cent) of the respondents had agriculture and animal husbandry practices as their primary occupation and possessed land holding up to 5 bighas only. However, this pattern of landholding in these villages might be due to relatively longer duration of settlement of the respondents. Similar findings were also
Dependent Variable

$\begin{array}{lllll}\mathrm{X}^{1} & \mathrm{X}^{2} & \mathrm{X}^{3} & \mathrm{X}^{4}\end{array}$

\begin{tabular}{l|l|l|l}
\hline 0.01 & $0.23^{*}$ & -0.10 & -0.16
\end{tabular}

$\begin{array}{lllll}0.10 & 0.05 & 0.38 * & 0.23 *\end{array}$

\begin{tabular}{l|l|l|l|}
0.08 & -0.08 & -0.09 & -0.05
\end{tabular}

\begin{tabular}{l|lll}
-0.07 & 0.05 & 0.03 & 0.06
\end{tabular}

\begin{tabular}{l|l|l|l|}
0.16 & 0.14 & 0.03 & -0.13
\end{tabular}

\begin{tabular}{l|lll}
-0.06 & 0.02 & 0.09 & 0.12 \\
0.03 & 0.02 & 0.11 & 0.07
\end{tabular}

\begin{tabular}{l|l|l|l}
\hline 0.03 & 0.02 & 0.11 & 0.07
\end{tabular}

$\begin{array}{lllll}-0.008 & 0.05 & 0.03 & -0.10\end{array}$

\begin{tabular}{l|l|l|l}
-0.10 & -0.09 & $0.24 *$ & $0.45^{* *}$
\end{tabular}

$\begin{array}{lllll}0.002 & 0.01 & 0.03 & -0.10\end{array}$


respondents were not that much and in fact cannot be termed as commercially sustainable for them. The above findings are in consonance with the result of Sathyanarayan et al., (2010) and Verma et al., (2014 a).

\section{Relational (Pearson's correlation) analysis between independent and dependent variables}

The positive correlation of age of the respondents with the assistance for being in the fringe areas $\left(\mathrm{X}^{2}\right)$ implied that, with advancement of age the respondent could enhance his land holding and also became able to derived assistance for being in the fringe villages. Similar result was also accounted by Verma et al., $\left(2014^{\mathrm{b}}\right)$. In case of education qualification, relational analysis revealed that it had positive and highly significant correlation $(\mathrm{r}=0.38, \mathrm{P}<0.01)$ with degree of assistance for livestock rearing in fringe areas $\left(\mathrm{X}^{3}\right)$ and positively and significantly correlated $(\mathrm{r}=0.23, \mathrm{P}<0.05)$ with veterinary support $\left(\mathrm{X}^{4}\right)$ (Table 3$)$.

From the positive correlation of educational level with the assistance for livestock rearing in fringe villages it can be easily surmised that higher level of education enabled the respondents to derive higher degree of assistance in livestock rearing which resulted in enhancement of their income. Similar was the reason with veterinary support also (Prajapati et al., 2016). Further, it was found that, annual income from agriculture \& A.H. had a positive and highly significant correlation $(\mathrm{r}=0.45, \mathrm{P}<0.01)$ with veterinary support $\left(\mathrm{X}^{3)}\right.$ and positive and significantly correlated $(r=0.24, \mathrm{P}<0.05)$ with degree of benefits for livestock rearing in the fringe areas $\left(\mathrm{X}^{3}\right)$. It is obvious that, increases in annual income from agriculture \& A.H. would naturally have a positive influenced over those two variables. The findings are in Consonance with the results of Das et al., (2005), Kutum (2011), Verma et al., (2014 $)$ and Borah et al., (2018).
A field survey was conducted to acquire the first hand information on socio-economic conditions of the fringe villagers of KNP. The Socio-economic life of the people in the villages was traditionally somewhat devoid of basic amenities like education and social participation etc. An important part of the socio-economic lives of these villages were out of the influence of urbanization.

Agriculture and animal husbandry was the base of livelihood but was more traditional than commercial. Livestock rearing was interwoven with socio-economic and cultural lives of the people.

Livestock rearing can be an alternative livelihood for the villagers provided that there is a remunerative well networked market, demand and mass media exposure. Rice was the principal crop but flood during rainy season had a definite impact on the livelihood. There used to be shortage of fodders for the livestock during the dry seasons as well as during the flood. This issue needs serious attention and investigation to do the needful, as early as possible. Thus, peasants need to be made aware about the fact that livestock rearing can be a promising alternative livelihood in their socio-economic and ecological conditions along with the agriculture. Thus, the findings may help the Kaziranga fringe villages Development Board, Assam, besides other non-government organizations in designing and implementing livestock and livelihood development programmes on a pilot basis for the study villages where poverty, backwardness and rich resources paradoxically coexist.

\section{Conflict of Interest: None declared}

\section{Acknowledgments}

The authors wish to express their sincere gratitude to the Department of Extension Education, College of Veterinary Science, A. A. U., Khanapara, Guwahati for providing us 
the opportunity to do the research work in the fringe villages of Kaziranga National Park.

The Authors also wish to express their gratitude to the Director, officials and other staff member of Kaziranga National Park authority who rendered their help during the whole period of the research work.

\section{References}

Baruah, P.P. 2000. Study of the hydrophytic flora of Kaziranga National Park, Assam, India. Annals of Forestry. 8(2): 170-178.

Borah, B., A. Borgohain, L.S. Khuman, G. Bordoloi, S. Payeng and Konia, T. (2018). Perceived benefits by the fringe villager of Kaziranga national park in respect of animal husbandry. International Journal of Educational Science and Research. 8 (2):1-8

Das, S. K. 2005. Study on livestock and livelihood of rural inhabitants in Sundarbans region of West Bengal. Ph.D. Thesis, Deemed Univ., IVRI, Izatnagar, U.P.

Hazarika, P. and Anand, U. 2001. Corelational analysis of the socio personal, economic, communication and psychological variables with knowledge and adoption behavior of the dairy farmers. Indian J. Soc. Res. 42(4): 251255 .

Karpagam, C. 2000: A Study on the Knowledge and Adoption Behaviour of Turmeric Growers in Erode District of Tamil Nadu. M. Sc. (Agri.) Thesis, University of Agricutural Science, Dharwad.

Kutum, A., R. Sarmah and Hazarika, D. 2011. An Ethnobotanical study on Missing

\section{How to cite this article:}

Biju Borah, Atul Borgohain, L.S. Khuman, Gautam Bordoloi, Raju Dewri, Mrinal Kalita and Kongkon J. Dutta. 2018. Socio-Economic Conditions of the Fringe Villagers of Kaziranga National Park (KNP), Assam, India. Int.J.Curr.Microbiol.App.Sci. 7(05): 2530-2536.

doi: https://doi.org/10.20546/ijcmas.2018.705.291 tribe living in fringe villages of Kaziranga National Park of Assam, India. Indian Journal of Fundamental and Applied Life Sciences. 1 (4): 45-61.

Nagesh, P.N. 2005. Study on Entrepreneurial Behaviour of Vegetable Seed Producing University of Agricultural Sciences, Dharwad, Karnataka.

Paincra, S.K., C.M. Dev and Mandal, BK. (2010). Information sources of tribal rice growers of Bastar District of Chhattisgarh. Journal of Communication studies. 27(3):135-139.

Prajapati, V.S., R.R. Singh and Chaudhari, G.M. 2016. socio-economic status of livestock farmers of navasari district of south Gujarat. International Journal of Agriculture Sciences. 8 (13) 1182-1183.

Sathyanarayan, K., V. Jagadeeswari, M.V. Chandrashekha, R.S. Wilfred and Sudha, G. 2010. Socio-economic status of livestock farmers of Narasapura village - A benchmark analysis. Veterinary World, 3(5): 215-218.

Sujeetha, T.N. and Anamica, M. 2017. Role Performance of Nilgiris Tribal Women in Animal Husbandry Operations. International Journal of Agricultural Science and Research. 7(2): 529-532.

Verma, A.K., N. Lal, S.R. Avhad and Hari, R. $2014^{\mathrm{a}}$. Socio-economic status of farmers rearing Kherigarh, an indigenous breed of cattle. The Asian Journal of Animal Science. 9 (2) 134-137.

Verma, A.K., N. Lal, S.R. Avhad, Niranjan, Manjusha, Jyoti, Sachan, Ranjana and Avhad, Sharad. $\left(2014^{\mathrm{b}}\right)$. Constraints faced by livestock farmers in rearing Kherigarh, an indigenous cattle breed of U.P. J. Veterinary Sci. Technol., 5 (3): 116. Farmers in Haveri District. M.Sc Thesis, 